\title{
THE PARENTS SCHOOL PROGRAM AT BATURRADEN NATURAL SCHOOL
}

\author{
Johar Alimuddin ${ }^{1}$, Mira Purnamasari Safar ${ }^{2}$ \\ joharalimuddin@gmail.com ${ }^{1}$ \\ STKIP Majenang ${ }^{1}$, State Institute on Islamic Studies Purwokerto ${ }^{2}$
}

\begin{abstract}
The aims of this research were to reveal: (a) The concept and aim of The Parent's School that is implemented in Baturraden Nature School (b) Activities that are done by parents when they are involved in children education. (c) Challenges from the implementation of the parent's school program. This research applied case study qualitative approach because it wanted to reveal what is behind the parent's school program that is implemented in Baturraden Nature School. This research also revealed any activity that involved the parents in the educational practice in Baturraden nature school. Moreover, it also revealed challenges as well as the things that attribute the implementation of the parent's school activity in Baturraden nature school. The research data was gained from interview, observation, and document analysis. The parent's school is a parent's involvement program in children education that is considered as parent's education needs model. The form of the parent's school was not only conference, but it was varied through a variety of activities such as outbound or games. The parent's school activity that has been joined by the students' parents were closed with reflection and question and answer with psychologist or expert. Parents were also involved in the children's assignment or project at home. This parent's school activity was high almost ever students' parents in the Baturraden nature school attended. This parent' school program was very helpful in monitoring the students' development as well as able to increase the children's potential.
\end{abstract}

Keywords: The Parent's School, Baturraden, Parent's Involvement. 


\section{INTRODUCTION}

Baturraden Nature School is also known as the school above the cloud. This name was due to the location of Baturraden nature school that is located 750 meters above the sea level and is located in the area of Perhutani's resin forest. Baturraden nature school is in the area of KemutugLor Village, BaturradenSubdistrict, Banyumas Regency, Central Java Province. Athough it is located in the mountain area and is far from the reach of public transportations, Baturraden nature school has many students and many students come from places that are far from the school.

As a nature school, curriculum in Baturraden nature school is mostly related to nature utilization as source and learning media. Learning activities in Baturraden nature school are mostly done in the nature or outdoor. The learning activities that are mostly done in nature do not mean that there are no classrooms, the classrooms (saung) are available, when the weather is not supporting the children will study in the saung.

Harmonious relationship between parents and teachers in Baturraden nature school can be seen from daily activities at the school. Before beginning the learning, the teachers (facilitators) will hold a welcoming activity. The welcoming activity is intended so that the students forget about what happens in their homes and become ready to start the learning. Whereas the students join the welcoming activity, the teachers will communicate with the parents related to the children's condition.

There are no food sellers in Baturraden nature school; it is because the location of the school is quite far from the people's houses. The children can still eat snack even though there are no food sellers. The school cooperates with the parents to make healthy snacks for the students. Some parents are involved to cook the snacks to consume during break time(Safar, 2015).

Baturraden nature school is a school that applies the parent's school program. This program is one of the facilities to connect the students with the parents, as well as the parents and the teachers. Through this activity, the students' parents are given directions and understanding related to the school's program or activity. The parents are also given knowledge about education theories and their role in their children's education. This knowledge makes the school able to cooperate well with the parents to maximize the students' achievement.

Education has three dimensions such as family dimension, school dimension, and society or surrounding dimension(Dewantara, 2013). From these three dimensions, family or parent dimension is the most important. First education that is received by a child is through his/her parents. After the child enters school age, the intensity of the child at home and at school is mainly at home. Through the explanation it can be noticed how important the role of parents in the children's education is.

The parent's school program in Baturraden nature school focuses on the significance of the importance of parents' involvement in the children's education. This is because many parents become care less when their children are enrolled in school. The parents' perceptions towards their role as parents only focus on the financial problems(Siregar, 2013).Parents mostly think that the most important thing is that their 
children can go to school and do not face problems in funding their education. The parents are too busy with their job so that they forget that their children need their affection.

When the children start to attend school, the parents tend to hand over their children's education to the school. "It is so wrong that parents think that it is enough if the children are sent to school"(Dewantara, 2013). The parents' trust to school has to be accompanied with parents' attention towards their children. Cooperation between school (teachers) and parents is necessary for optimal children's development. School will not be able to make the children's potential become well developed without the involvement of the parents. The parent's school program that is held in Baturraden nature school is very helpful in developing the children's' potential holistically. The involvement of parents can complete education that is experienced by the children at school. Schools tend to focus education more on knowledge aspect, whereas parents will complete it on attitude or character aspect.

The involvement of parents in education gives opportunities for the children so develop their potential optimally. Proves from some research showed that children, whom their parents take participation in the children's education in school, have bigger opportunity in educational success(Mathews, 1989). The parent's school program attempts to involve parents in the children's education at Baturraden nature school. The involvement or all parents of the students in Baturraden nature school affect the education success of the students and it is shown by optimal development of the students according to their potential.

\section{METHOD}

This research used case study qualitative approachThis research revealed that the parent's school program that is applied at Baturraden nature school. The phenomenon that became the main research focus is the implementation of the parent's school program and activities that were done in the parent's school program at Baturraden nature school.

The respondents of this research were two parents, two teachers, two students, and the headmaster.The aims of this research were to reveal: (1) The concept and aim of The Parent's School that is implemented in Baturraden Nature School (2) Activities that are done by parents when they are involved in children education. (3) Challenges from the implementation of the parent's school program.

The research data is in the form of oral and written information obtained through interviews, field observation of school activities of parents and documentation. Interviews were conducted to find out various matters related to his parents' school program at Baturraden natural school through the snowball sampling method. Interview conducted until found the data about school program of parents needed. If the data are considered incomplete interviews can be done on others who are considered more able to help the collection of data becomes more complete. Observations were made to find out firsthand the activities undertaken in his parents' school program at Baturraden natural school. Documentation method is carried out through the examination of documents related to the parent school program. 
Data analysis is done based on(Matthew B. Miles, 2014)through the following steps: (1) data collection is data collection process conducted through interview, observation, and documentation, (2) data condensation is sorting process, focusing and simplification of data in accordance with the theme, (3) data presentation that is organizing and grouping data to facilitate the making of description and conclusion, (4)conclusion and verification is giving meaning and interpreting data already got.Four steps are dynamic after making a conclusion can be done data collection again because there is data that needs to be obtained again. To strengthen the data also triangulation method and triangulation of sources. Triangulation method is done by connecting data obtained from three methods namely interview, observation and documentation. Triangulation of resources is done by linking data obtained from interviews with various sources.

\section{RESULTS AND DISCUSSION}

This research successfully revealed some matters related with the parent's school program at Baturraden nature school. Some matters that were revealed were (1) the concept and the aim of the parent's school program at Baturraden nature school; (2) The activities that were experienced by the parents and the children in the implementation of the parent's school program; (3) The challenges that were faced in the implementation of the parent's school program at Baturraden nature school.

\section{Concept and Objectives of The Parents School Program}

The implementation of education in Baturraden nature school focused on four education pillars. Those four pillars were Character, LogicalThinking, Leadership and Enterpreuner. The students of Baturraden nature school were hoped to have good character, able to solveproblems through good logical thinking, become wise leader, and able to be entrepreneur to survive. Those for pillars were the aims of the implementation of educational activity in Baturraden nature school.

Those four pillars could be reached though great synergy between the students, teachers, and parents. Good cooperation between those three elements could make the attainment of four pillars of the nature school and children potential development become easier. The parents have to be involved in the children's education because parents have great influence towards the children's behavior.

The parent's school in Baturraden nature school was a communication facility between the school and parents. The concept of the parent's school was based on four nature pillars, education dimension according to(Dewantara, 2013), the development of knowledge that also changes current education pattern and unique human characteristics. The concept formulation of the parent's school in Baturraden nature school were (1) parents are the first and the main educators for children (2) good education has to involve family, school, and surrounding dimensions (3) education that was experienced by the parents are different with current education nowadays (4) every child is unique, she/he has individual characteristic and potentials. 
The parent's school was a routine meeting that was done once in a month. This meeting had some objectives as follows: (1) Parents know their position and role in their children's education (2) parents are involved in their children's education according to their portion (3) help the school and the teachers in creating good programs that are in line with the children's potential (4) are involved as well as help activities at school.

The parents need to know that they have quite great role in the children's education. Through the parent's school, the students' parents are asked to care about their children's education even though they were enrolled in school. The parents did not hand over their children's education fully to the school because there were contributions from the parents. The dimension of parents' involvement on the children's education according to (Wendy S. Grolnick, 1997)werebehaviour, cognitive-intellectual, and personal. The parents' involvement is related to participation at school (for example, attending parents and teachers meeting as well as attending school activities) and at home (helping to do homework and asking about school). The intellectual cognitive involvement included takes the children to do activities that can trigger their intellectual such as going to library and talk about current activities. Personal involvement is by knowing about the children's school and follow what is happening with the children at school.

Parental involvement is good for children's development but the involvement must be in accordance with the portion. Involvement of parents who always help their children in doing tasks and homework just does not help. Involvement is too excessive because if it continues then the children will become spoiled and continuously rely on his parents. Finally, it was not the children who go to school or studying but their parents. Help the child according to the portion so they can also develop well. Through the parent's school, parents can know what their portion of involvement in children's education is. Communication that exists between teachers and parents through the parent's school can be used as teacher guidance in giving tasks to the children, in accordance with their development.

Parents need to know that current education differs from education as they went to school before. The development of science and technology makes the pattern of education also changed. Parents do not need to compare the education they experienced with the education of their children today. Times have changed and are growing. Teach your children according to their age, for they live in their age not in yours. Indeed, they were created for their age while you were created for your age(Ahmad, 2017). Education is dynamic; therefore, parents need to follow the development of the age so that they can be maximally involved in the education of their children.

Parental involvement does not just help the child in completing the task but also can help the school and the teachers. Parents can become members of parent and teacher communities, becoming a learning resource for students at school according to their profession or area of expertise. (Hornby, 2011)described the contribution of parents in (1) policy (2) learning resources (3) Collaboration (4) information.

Many studies have concluded that parental involvement in children's education has a positive impact. (Charles Desforges, 2003)in their study concluded that parents' involvement in children's education has a strong impact on their attainment and selfadjustment. (Hornby, 2011)suggests the benefits of parents' involvement that is beneficial 
to children, teachers, and parents themselves. Benefits for children involving parents make them better in terms of attitudes, behaviors and attendance at school, as well as in mental health. The benefits for teachers of effective parents' involvement are improving the relationship between teachers and parents, teachers' morale, and school climate. The benefits for parents in their involvement in children's education are increase of parents' trust and satisfaction in childcare, as well as the increase of interest in their own education. (Mega Silvia Retnaningtya, 2015)suggested that parental involvement has a diverse impact on each individual but it can generally be said that parental involvement has a positive impact on child development. (Keith Robinson, 2014)explained that parent-school relationships become the centre of encouragement to increase parents' involvement. (Cotton Kathleen, 1989)stated that the more intensive the parents be engaged in children's learning the more the children's achievement is. This applies to all types of parental involvement and to all student types and ages. Based on those studies, it is appropriate if the school involves parents in the implementation of education.

The parent's school program was the beginning of many parental involvements in children's education that was held at Baturraden nature school. Parents' understanding about their role in children's education and good communication with school and teachers can increase parental involvement in children's education. This involvement will obviously give positive impact on the children's development during school time at Baturraden natural school.

\section{Types of The Parent's School Program}

The parent's school program at Baturraden nature school was carried on regularly every once a month. The event was held on the last Saturday of every month. The enthusiasm of the parents of the students wass also very good, this was in accordance with the data stating that more than $90 \%$ of parents of learners at Baturraden nature school present in this activity. Parents who became respondents stated that this activity wass a gathering activity as well as to gain knowledge about educating a good child. The parents of Baturraden nature school students tried to attend this activity unless if there really was an $\mathrm{n}$ event that can not be abandoned. The parents were very enthusiastic in this activity because they can learn as well as stay in touch with fellow parents whose children attend Baturraden Nature School.

The types of activities of the parent's school were initially seminar and discussion of children's education. The implementation of those activities that were done in routine were considered boring then from this appeared other activities involving parents in children's education. Besides seminars, these activities were also done in the form of working with parents with specific tasks, as well as parents became a source of learning for students in certain materials. Outbound activities have also been done in the implementation of parent's school program. Parents were also invited to perform the same game or activity performed by their child. Besides nostalgia through these activities, parents can know that the learning activities undertaken at school were fun activities. At the end of the activity, this was always closed with discussion or questions and asks activity with competent sources. 
Whatever types of the activities, as long as the parents have their involvement in the children's education in school whether it is direct or indirect, this can be called as parental involvement.(Charles Desforges, 2003)contended that parental involvement is any kinds of activities that involve parents to reach great result of the children's education. The activities can be in form of good parenting at home, helping with homework, talking with teachers, attending school events, until taking part in school management. From the various activities, the most effective parent involvement is focused on supervising children's learning activities, parents have high academic expectations for their children, and helping with their children's reading habits. High academic expectations must be accompanied by a parent's understanding of good children's education (Maria Castro, 2015). A good understanding can be obtained through the school activities of parents conducted in the natural school of Baturraden.

Parental involvement model in children education is grouped into two namely parents' needs and parents' contribution. Parents' needs include (1) Communication with teacher (2) Liaison/relationship between parents and school (3) Education (4) Support (Hornby, 2011). Communication between teachers and parents are required so that education can happen continually in school so that when discipline is taught at school, it will also be taught outside the school and at home. This discipline lesson outside the school is taught by parents. Relationship between school and parents is required so that education in school can be done continuously even after the students are home. Not only the children, parents also need education about how to take care of their children and how they involve themselves in the children's education. Parents also need support from teachers; support here means support in form of counseling.

Whereas parents' contribution model includes (1) policy (2) learning resource (3) Collaboration (4) information. Policy contribution meaning that parents give contribution towards policy applied by the school or teachers in the children's education activities. Parents become the member of parents and teachers community in school. Contribution as learning resources meaning that parents become source person in learning activity that is done by the students according to their profession and expertise. Collaboration contribution meaning that parents and teachers help the students to finish task from teachers. Information contribution meaning that teachers deliver the students' characteristics to teachers so that the teachers can design learning activities that are precise and according to the children's potential.

According to Hornby's opinion on parental involvement model it can be said that the parent's school program in Baturraden nature school was a parents' needs model in terms of education. Activities in form of seminar was a proof that parents need education on how to take care of their children and be involved in the education of children. And then, the continuance of the parent's school program are considered as parental involvement model. Working together activities with parents for example was categorized as collaboration model. Parents collaborate with the children to finish tasks that were given by teachers, for example drawing lunar eclipse, and making African forest animal mask.

The parent's school program at Baturraden nature school included a model of parenting needs on the educational aspect. However, this program was the first step in involving parents in the implementation of education in Baturraden nature school. Starting 
from this program, models of parental involvement in Baturraden nature school could be done. Through this program, parents also became more active to engage in the education of their children.

\section{Challenges in The Implementation of The Parent's School Program}

Every activity must have challenges in its implementation, but those challenges must be faced in order to make the activity even better. The parent's school program was an activity that involved parents of Baturraden nature school student. So far, there has been no significant obstacle in the implementation of this program. The attendance rate of parents in this program was quite good, about $90 \%$ of parents were present every month. The biggest difficulty that had been experienced in the implementation of the parent's school programs was the busyness of parents. Parents could not continuously attend this program.

The parent's school program was part of parents' involvement in children's education. The issue of parental involvement is complicated (Keith Robinson, 2014). The complexity became a challenge in continuing the effort to involve parents in children's education. There were four challenges of parental involvement such as family and parents individual, factor of the child themselves, parents and teachers relationship factors, as well as social factors.(Garry Hornby, 2011). Parental involvement in children's education was very complex because it was related to the four factors mentioned earlier.

Focusing on parental involvement makes other factors forgotten. Discussing about the parental involvement what was discussed was only the dimensions of family and school, whereas society or environment dimensions were neglected. Parental involvement is important but the environmental aspects also need to be considered.(McNeal, 2014)Many researchers are concerned about parental involvement in children's education but forget the social context, whereas the context in schools has a considerable effect on children's education. A holistic approach in viewing parental involvement in children's education needs to be put forward. This holistic approach can be used with reference to family and individual factors of parents, the child's own factor, parent-teacher relationship factors, and social factors. A holistic approach that takes into account these four factors can maximize parental involvement in children's education.

The implementation of the parent's school program as an educational model that parents need can be the starting point of parents' understanding about children's education. This is because the problems that arise in the parent's school program at Baturraden nature school was parents factor, that is the perception of their duties were only in terms of cost and busyness in work. If problems that arise in other factors it would need a different handler not through the parent's school program. If problems arise from the teachers factor then the parent's school program can not solve the problem. Policies that can solve these problems are the policies of the principal or a number of higher policy makers. 


\section{CONCLUSIONS AND SUGGESTIONS}

\section{Conclusion}

Based on the (Hornby, 2011)parental involvement in children's education is divided into two models. The first model is the model of parent needs that includes Communication with Teachers, Liaison / relationship between parents and school, Education, Support. The second model is a contribution model that includes policy, learning resources, collaboration and information. His parents' school program at Baturraden natural school is included in the model of parent's needs in education.

The existence of the parent's school was the beginning of a variety of parents' involvement in children education that was implemented in Baturraden nature school. Education in Baturraden nature school was not only for the children, but also for the parents. The parent's school program was an education facility for the parents to know various things about their children's education and their role in the children's education. The forms of the school activities were seminar and discussion. Starting from the parent's school program and then developed into other parents' involvement model that was applied in Baturraden nature school such as collaboration model through cooperation with parents and learning model when the parents became resource person or guest teachers in the learning implementation.

\section{REFERENCES}

Ahmad, S. (2017, Januari 27). Didiklah Anak Sesuai Zamannya. Riau, Riau.

Charles Desforges, A. A. (2003). The Impact of Parental Involvement, Parental Support and Family Education on Pupil Achievements and Adjustment: A Literature Review. Queen's Printer.

Cotton Kathleen, K. R. (1989). Parent Involvement in Education. Retrieved from http://www.nwrel.org/scpd/sirs/3/cu6.html

Dewantara, K. H. (2013). Pemikiran, Konsepsi, Keteladanan, Sikap Merdeka Buku I Pendidikan. Yogyakarta: Majelis Luhur Persatuan Taman Siswa.

Garry Hornby, R. L. (2011). Barriers to Parental Involvement in Education: An Explanatory Model. Educational Review, 63(1), 37-52.

Hornby, G. (2011). Parental Involvement in Childhood Education (Building Effective School-Family Partnership). New York: Springer.

Keith Robinson, A. L. (2014). The Broken Compass (Parental Involvement With Children's Education). Harvard: Harvard University.

Maria Castro, E. E.-C.-M. (2015). Parental Involvement on Student Achievement: A Metaanalysis. Educational Research Review, 2-24.

Mathews, B. J. (1989). Learning Through An Integrated Curriculum Approaches and Guidelines. Victoria: Ministry of Education.

Matthew B. Miles, A. M. (2014). Qualitative Data Analysis A Methods Sourcebook (3 ed.). Los Angeles: Sage Publications. 
McNeal, R. B. (2014). Parent Involvementand Student Performance: The Influence of School Context.

Mega Silvia Retnaningtya, P. P. (2015). Keterlibatan Orang Tua dalam Pendidikan Anak di TK Anak Ceria. Jurnal Psikologi Pendidikan dan Perkembangan, 4(1), 9-17.

Safar, M. P. (2015). Sekolah Di Atas Awan. Bandung: STEMBI.

Siregar, N. S. (2013). Persepsi Orang Tua Terhadap Pentingnya Pendidikan Anak. Jurnal Ilmu Pemerintahan dan sosial Politik, 11-27.

Wendy S. Grolnick, C. B. (1997). Predictors of Parent Involvement in Children's Schooling. Journal of Educational Psychology, 538-548. 